\title{
Moderating Effect of Brand Equity on Relationship Quality in Chain Restaurant Industry: A Conceptual Paper
}

\author{
Lo Ying Tuan ${ }^{1}$ Ahmad Jusoh ${ }^{1}$ \\ ${ }^{1}$ Faculty of Management and Human Resource Management, Universiti Teknologi \\ Malaysia, Malaysia
}

\begin{abstract}
The purpose of this paper is to discuss at a conceptual level on the moderating effect of brand equity on relationship quality in the chain restaurant industry. A conceptual model of relationship quality expanded with brand equity construct is proposed. The paper finds brand equity moderates the relationship between patrons' dining experience and relationship quality in achieving customer loyalty. The paper hopes to provide managers in services, particularly those in the restaurant industry, relevant information to assist in improving their relationship marketing programs.
\end{abstract}

Keywords: Patrons' Dining Experience, Relationship Quality, Brand Equity

\section{Introduction}

The way we relate and communicate with each other is called relationship. Along with time the old approach of productoriented marketing has been replaced by customer-oriented relationship marketing, where satisfaction becomes the critical factor. However, it was later found that meeting customer satisfaction alone is no longer enough to ignite loyalty in them. This phenomenon has started a spark and marketers found that there should be a relational bond between a firm and customer and this relationship is ought to be maintained [1]. This relational bond is referred as relationship quality. A good and maintained relationship quality between a company and its customers is considered long-term marketing success which will eventually leads to loyalty [2].

The chain restaurant industry is no exception. Large numbers of chain restaurants are channeling more staff and marketing resources into relationship quality management [3]. Restaurants that maintain quality relationships with their patrons are able to gain competitive advantage in the market.

While current research clearly indicates that a company's relationship quality and customer loyalty are major factors influencing long-term profit and performance, our understanding of the factors that influence the formation of relationship quality and loyalty is relatively weak. Furthermore, Hyun [3] highlighted that there has been no previous theoretical background on relationship quality and brand equity in the chain restaurant industry. $\mathrm{He}$ suggested that the relationship should be expanded with a brand equity construct. Previous studies have empirically verified brand equity's impact on chain restaurant performance [4] where it was found that brand equity moderates the relationship between customer's perception and loyalty [5]. While customer's perception influences to the strength of relationship quality [6], hence it is believe that brand 
equity will moderate the relationship of relationship quality and its antecedents. In our case, moderate the patrons' dining experience (PDE) with relationship quality.

\section{Literature Review}

\subsection{Relationship Quality}

Relationship quality refers to the strength of a relationship measured on how well a company has met its customers' needs, perceptions, goals and desires [6]. A strong relationship quality indicates how well the customer has been satisfied with the service provider's past performance, their trusts on the service provider's future performance, and their wishes to maintain the relationship [1]. In general, the construct of relationship quality is conceptualized as a multi-dimensional construct. Relationship quality is conceptualized into three main dimensions; trust, satisfaction and commitment [2][6][7]

Satisfaction is found to be the main determinant in the relationship between service provider and customer [1]. Satisfaction is referred to the degree to which the performance meets customers' expectation [8]. Payne and Holt [8] have argued that satisfaction is not only evaluated by expectation towards the core product and expectation towards the supplier, but also other values as well such as benefits received. Satisfaction by its nature is able to provoke future actions by partners. Therefore, they suggested that satisfaction will lead to the longterm continuation of relationships.

There has been vast discussion in the literature on the concept of trust in supplier and customer's long-term relationships [6]. In general, most researchers agree that trust plays an important role in influencing the supplier and customer's relationships. It has been widely debated that a customer is more likely to maintain the relationship with the supplier he/she trust rather than risking to have uncertainties in building new ones.

There are also a number of researchers in their research stresses out the significant of the construct of commitment in building and maintaining long term relationships [2][9]. They stated that relationships are built on the foundation of mutual commitment. Many authors regard commitment as an important dimension of relationship quality because it is a critical variable in measuring long term relationship between buyer and seller [2][7]. Robert et al. [2] also stated that the customer's level of commitment to an organization as an indicator of the strength of relationship.

\subsection{Loyalty}

According to Oliver [2], he defined loyalty as repeated patronage where loyal customers produce huge amounts of revenue and demand with less time and attention. Because of this, loyal customers are important assets of a company. Therefore, many companies select loyalty as their fundamental business goal because loyal customers purchase the same brands against all odds and at all costs [2]. For many years, the relationship between satisfaction and loyalty has been an important research topic in marketing. It is widely recognized that high levels of satisfaction will result in loyal customers [2]

Oliver [2] further stresses that satisfaction is necessary to loyalty, but customer satisfaction becomes less important as loyalty begins to form. Specifically, Hallowell [10] examined the relationship between satisfaction, loyalty, and profitability which supported the finding that satisfaction is positively and significantly related to the firm's loyalty and profitability. In other words, positive satisfaction is a key antecedent of loyalty 
formation. Additionally, some researchers have suggested a mediating role of trust in the relationship between satisfaction and loyalty [11][12].

\subsection{Patrons' Dining Experience (PDE)}

In the restaurant industry, complex attributes influence patrons' behavior. Different researchers have proposed various attributes to explain patrons' behavior, but only five of these are widely accepted. The identified attributes are of food quality, price, service, location, and environment [3].

\subsection{Brand Equity}

One critical factor in the success of chain restaurants and other service firms is the development of a strong brand [4]. In the other words, by increasing one's brand equity. By definition, brand equity is "a set of brand assets and liabilities linked to a brand, its name, and symbol that add to or subtract from the value provided by a product or service to a firm and to that firm's consumers" [13]. Hyun and Kim [4] maintained that brand equity as an important source of capital in the restaurant industry. Recent study by them [4] on dimension of restaurant's brand equity consist of four dimension as proposed by Aaker [13] which are brand awareness, brand image, perceived quality, and brand loyalty.

\section{Conceptual Framework}

The proposed model was developed based on the review of theoretical and empirical studies in related area.

The patrons' dining experience (PDE) consists of attributes of food quality, price, service quality, location and environment. Relationship quality is affected by PDE, which in turn affects loyalty. The attributes influencing PDE will act as a form of relational bonds that are able to strengthen and maintain a quality relationship. This will eventually lead to positively impact on loyalty [3]. Empirically, previous research has provided evidence in supporting the relationship between PDE and relationship quality. In the findings, it is also found strong evidence of the linkage between relationship quality with loyalty [3]. Palmatier et al. [7] also found that relationship quality measured by trust and satisfaction is a strong determinant of loyalty.

Brand equity will be functioning as a moderating variable. Supported by previous research, brand equity was found to show impact on chain restaurant performance [4]. Hence the moderating effects of brand equity on relationship between attributes influencing chain restaurants patron's behavior and relationship quality should not be ignored.

The proposed conceptual framework is presented in Figure 1.

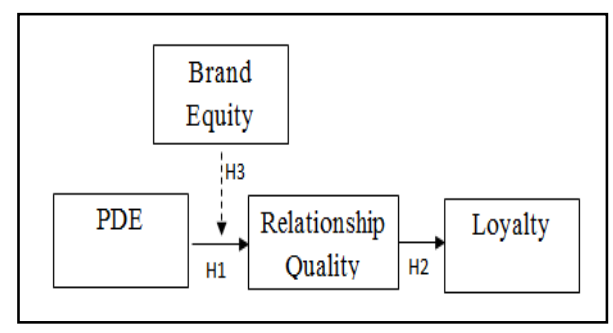

Fig.1: Proposed Conceptual Framework

The proposed model focuses on the impact of PDE on relationship quality and finally on loyalty with brand equity as moderator. Therefore, the following hypotheses were formulated:

H1: PDE will positively affect relationship quality.

H2: Relationship quality positively affects loyalty.

H3: Brand equity moderates the relationship between PDE and relationship quality. 


\section{References}

[1] Roberts, K., S. Varki, and R. Brodie. (2003). Measuring the quality of relationships in consumer services: An empirical study. European Journal of Marketing 37 (1/2): 16996.

[2] Oliver, R. L. (1999). Whence consumer loyalty? Journal of Marketing 63 (5): 33-44.

[3] Hyun. S. (2011). Predictors of relationship quality and loyalty in the chain restaurant industry. Cornell Hospitality Quarterly May 2010 vol. 51 no. 2 251-267.

[4] Hyun S.S. and Kim W., (2011) Dimensions of Brand Equity in the Chain Restaurant Industry, Cornell Hospitality Quarterly November 2011 vol. 52 no. 4 429-437.

[5] Hsieh A. T., Li C. K., (2008). The moderating effect of brand image on public relations perception and customer loyalty, Marketing Intelligence \& Planning, Vol. 26 Iss: 1, pp. $26-42$.

[6] Wong, A., \&Sohal, A. (2002). An examination of the relationship between trust, commitment and relationship quality. International Journal of Retail \& Distribution Management, 30(1), 34-50.

[7] Palmatier, P., Dant, R. P., Grewal, D., \& Evans, K. R. (2006). Factors influencing the effectiveness of relationship marketing: A metaanalysis. Journal of Marketing, 70(October), 136-156.

[8] Payne, A., \& Holt, S. (2001). Diagnosing customer value: Integrating the value process and relationship marketing. British Journal of Management, 12, 159-182.

[9] Fullerton, G. (2005). How commitment both enables and undermines marketing relationships. European Journal of Marketing, 39(11/12), 1372-1388.

[10] Hallowell, R. (1996). The relationships of customer satisfaction, customer loyalty, and profitability: An empirical study. International Journal of Service Industry Management 7 (4): 27-42.

[11] Roman, S. (2003). The impact of ethical behavior on customer satisfaction, trust and loyalty to the company: An empirical study in the financial services industry. Journal of Marketing Management 19 (9/10): 915-39.

[12] Singh, J., and D. Sirdeshmukh. (2000). Agency and trust mechanism in consumer satisfaction and loyalty judgments. Journal of the Academy of Marketing Science 28 (1): 150-67.

[13] Aaker, D. A. (1996). Measuring brand equity across products and markets. California Management Review 38 (3): 102-20. 